\title{
Care and Services for the Welfare of Geriatric Population in India: A Critical Appraisal
}

\author{
S. John Kaviarasu ${ }^{1}$ and J. Jai Dinesh ${ }^{2}$ \\ ${ }^{1 \& 2}$ Assistant Professor, School of Human Excellence, Loyola College (Autonomous), Chennai, Tamil Nadu, India \\ E-Mail: johnkavia@gmail.com, jaidineshj@gmail.com
}

\begin{abstract}
A paradigm shift from the joint family system to nuclear family, a fast changes in lifestyles, changing and fluctuating social values and the pressure of working conditions create impediment for the younger generation at present in loving and caring their elderly parents. The age-old traditional institutions in the country are not successful and sometimes failing in accommodating the needs of their elderly, it is the duty of the state to evolve good policies and design necessary programmes for the welfare of the geriatric population to keep the elderly alive and safeguard them with human dignity. It is a constitutional obligation. The present paper analyses in detail about the various policies and programmes of the elderly and how they are implemented from time to time of the various states in India. The findings show clearly about the large scale inadequacy of political economy of elderly welfare in India. The states could not do anything concretely to cater to the needs of the growing geriatric population in India as they are suffering from insufficient availability of resources. If this is the state of elders in India for more than two decades, how the poorer sections of the geriatric population in the society will have dignified living and respect. It reflects clearly at every level on the part of the state, community and family for seeing/finding the lack of genuine commitment in caring the elders and for their welfare in India. The younger generations of today have sidelined to capture and also to possess the wisdom and experiences of the elderly. Instead they are going after the materialistic values. Therefore, they do not give importance in meeting out the needs of their own elders' care. This has resulted in utterly pushing the geriatric population to the state of helplessness.

Keywords: Geriatric Population, Policies, Health, Family, State, Political Economy, Lifestyles, Materialistic Values, Helplessness
\end{abstract}

\section{INTRODUCTION}

It is evident from the recent times that the younger generations have started paying so much attention to enjoy the technological developments and economic advancements. This has merely reflected in not meeting out the needs of elders and also failed to recognize the status of elders at present. It is primarily due to the changes in terms of technology and employment, joint family system has completely diminished and younger generations have embraced the nuclear family system. It is obvious that elderly people always show their willingness to live with their family members and relatives. But it is not taking place in India at present due to the fact of nuclear family system for varied reasons and causes. It is a common fact in India to see the poverty conditions, status of low productivity, huge problems of unemployment, a scanty budget allocation to attend to the needs of the poor on their health and security, poor welfare infrastructure to care the elders and a low quality of life for the vast chunk of geriatric population in comparison to western countries. These problems need to be attended immediately to show not merely for the mark of respect to elders, but they have contributed so much in building the economy of the nation by their hard work and also they have paved the way for the present generation to shine in every field of developments. Every state in India should do something concretely and constantly for the welfare of the geriatric population who are solely dependent upon our support to keep their heart and soul together.

\section{DEMOGRAPHIC AGEING}

Population ageing is a multi-dimensional phenomenon, which is unavoidable and irreversible biological process of life for everyone. Ageing has significant consequences on economy, society and politics. There are four classifications of geriatric population. 60 to 65 age group is called YoungOld, from 65 to 75 age group is called Middle-Old, 75 to 80 is called Old-Old and finally oldest old are in the age group of 80 plus. Geriatric population in their 80 's are called 'octogenarians', in 90s are called 'nonagenarians' and 100+ are called 'centenarians'. There is a reverse relationship between old age and size of such population, which keeps on decreasing in any society as the age increases beyond seventy. Geriatric populations of the above categories use to vary from society to society and from one time to another. It is based on the needs of elders on physical, psychological economic and social, the support system and self-sustaining capacities vary.

There are three types of ageing in a population based on three dimensions of ageing and each one is associated with each other. They are called as physiological Ageing, Psychological Ageing and Social Ageing (W. Andrew Achenbaum 1995).

\section{INDIAN SCENARIO OF AGEING}

It is found from the last five decades, the status of elders started losing their family values, experiencing the emergence of conflicts within their family and also huge gap between younger and older generation. A vast majority of the geriatric population, irrespective of rural or urban, is 
totally dependent on the younger generation for their physical health, psychological health and personal expenses. Most of the elders start suffering from emotional insecurity and isolation after losing their spouses. However, this may not be true in case of everyone. Many people at the age of sixty or above remain very healthy and active in life. The life style including exercise, diet, and regular health checkup help elderly to enjoy meaningful and active life (Ansari 2000).

Statistical data shows that India is growing old from 77 million to nearly 177 million in another 25 years. The average life expectancy is increased from 36 years in 1951 to 66 years today. In India, population ageing has been phenomenal in recent decades as the table below depicts

TABle I Percentage Of 60 Plus Populations ACross States In India

\begin{tabular}{|l|c|}
\hline \multicolumn{1}{|c|}{ Name of the state } & Percentage \\
\hline Assam & 6.5 \\
\hline Delhi & 6.5 \\
\hline Jharkhand & 7.1 \\
\hline Madhya Pradesh & 7.1 \\
\hline Uttara Pradesh & 7.1 \\
\hline Bihar & 7.2 \\
\hline Rajasthan & 7.3 \\
\hline North Estern States (Excl Assam) & 7.3 \\
\hline Haryana & 7.6 \\
\hline Jammu \& Kashmir & 7.7 \\
\hline Chhattisgarh & 7.9 \\
\hline Gujarat & 8.4 \\
\hline Uttrakhand & 8.5 \\
\hline West Bengal & 8.5 \\
\hline Maharashtra & 9.0 \\
\hline Odisha & 9.0 \\
\hline Andhra Pradesh & 9.1 \\
\hline Karnataka & 9.2 \\
\hline Punjab & 9.7 \\
\hline Himachal Pradesh & 10.3 \\
\hline Tamil Nadu & 12.3 \\
\hline Kerala & 2011 \\
\hline
\end{tabular}

Source: Computed from ORGI (2011), Census of India, 2011, Office of the Registrar General and the Census Commissioner of India, Ministry of Home Affairs, Government of India. www.censusindia.gov.in.

Historical evidence shows that elders were given much respect in India due to a value based joint family system and therefore, the happenings of elders in different pockets of India has never been reflected and deliberated as a big problem but thought of a western problem. But the situation has been changing and old age is now being considered a burden for the younger generation because of their busy life. (Ansari 2000).
As of now, elderly poor in India are more vulnerable than younger persons to social and economic hardships because "in the process of development, poor sections lose ground in relative and perhaps also in absolute terms" (Arun Bali, 1999). This clearly reflects that not only elderly population would increase but also a big increase would be seen among the population of elderly poor.

Irudaya Rajan (1999) clearly spelled out through his research that a fast growing number of geriatric populations is attributed to demographic transition. Moreover, the deteriorating condition among elders is considered as the end result of the fast eroding traditional family system in the wake of rapid modernization and urbanization.

It is shocking to notice that one in eight among the older persons in the world now lives in India. The population of India is ageing in two ways- (a) Ageing to reduced fertility; and (b) Ageing due to reduced mortality.

Hindu society has been totally led by male-controlled values based on the institution of caste and joint family system. But now, the joint family system is gradually substituted with nuclear household due to the characteristics by individuality, independence, autonomy and desire for privacy. After the education, the grownup wards migrate to different cities and metropolis of India often experience difficulty in coping with urban living expenses and therefore their elderly parents are left in their own villages itself and thereby they begin to experience the anxiety of loneliness and isolation. This clearly points out the inability of their wards to provide care giving to elderly parents. Moreover, the fast changing roles, higher expectations of women, willing to have privacy life, livelihood options, job ambitions to climb higher and higher and desiring for a prospective employment outside the home have drastically reduced the quality time of caring to the elderly parents in the family. In spite of such problems, the parents are expressing their utmost preference to jointly live with their children. The most preferred choice of the parents is to live with the eldest son and the least preferred choice is living with their daughter in Hindu society. However, this traditional belief often puts the elder ones into a fix. (Irudaya Rajan et al. 1999)

It is an undeniable fact that geriatric populations are absolutely dependent on their family members for the rest of their lives. Their life becomes utterly miserable when they do not have an adequate access to meet their basic and physical needs such as food, clothing, and shelter. It is a common phenomenon that geriatric populations are suffering from diabetes, high blood pressure, depression, dementia and high blood pressure and paining so much on their joints and back and so on. It is due to busy schedule of their family members every day on their routine activities, the children tend to ignore their elderly parents and allow them to suffer. 
Sometimes older persons are faced with economic disabilities when a management responsibility for matters relating to finances, property or business when shifted to children pushes the older persons into a new status of economic dependence (Ansari, op.cit).

It is evident that elderly women are totally dependent than the elderly men. About 29 per cent of rural elderly and 24.4 per cent of urban elderly are financially independent. Beyond the age of 60 plus, the status of widowhood is extremely high among females than males. The widows are left with a meagre or no assets of their own and also shocking to find that they do not have a source of income to sustain the rest of their living on this earth. Single persons, particularly women, are most vulnerable in old age as few people are willing to take care of them. (Gorman M. and Randel J, et al. 1999). Having understood the plight and suffering the elderly population, Government has not initiated in providing sufficient facilities for them to ensure their dignity of life. Even though it has been working for the welfare of the elderly but these facilities are reaching the older people or not, especially in rural and remote areas, is quite unclear. The government intends to provide all basic facilities but because of limited resources it is unable to provide decent services.

\section{NEEDS OF THE ELDERLY}

The survival needs of the elderly completely vary according to their conditions, consequences and magnitudes. Such needs include having assistance for their mobility, medications and daily care. It is so important for the family members and guardians to fully understand the awareness of elderly about their various needs and requirements and take up the complete reasonability to care of them. It is so occurring for some elderly people that their physical needs are met but their family members tend to forget in fulfilling the need for emotional attention and support. Not only the emotional but also the social needs of the elderly can be met by spending quality time of caring the elders, making frequent visits to enquire them how they live and what they need, talking to them over the phone once a day at least, having meals with them at home and occasionally taking them for meals at their favorite restaurants, making them feel happy by talking to them, singing a sing, taking the grandchildren to play with them, cracking jokes and sharing of joyous moments of their fast. If the minimum basic needs of the elderly persons are not met either by their family members or close relatives, they will face utter loneliness, depression, dejection, hopelessness to live, and ill-health further leading to numerous complications on their physical and psychological health. Thus the different needs and requirements of the elderly should be adequately taken into consideration by the family members, society and the government. It is so important by the government to play a key and significant role in providing better facilities to elderly with regard to their health, nutrition, pensions and other social security benefits (Chaudhury D.P. 1992).

\section{CONSIDERATIONS OF THE ELDERS' WELFARE}

The non-profit organization namely Help Age India is doing wonderful services for the care and welfare of the poor and marginalized elders with the support of state sponsored programmes. Still they are looking for many such support programmes from the state governments to care the elderly.

Some of the elderly are taken care by their family members and their relatives, but the majority of informal care providers, being poor and lack of adequate infrastructure, could not sustain in providing adequate medicine, food, and living spaces for the marginalized and abandoned elderly. This situation calls an attention of everyone to have the responsibility and moral duty to take care of the health and other needs of the elderly because of whom we are in existence today.

On the other hand, social workers, social scientists, planners and policy makers should make an attempt to assess the needs of the suffering elderly and try to fulfill the same. Introducing and bringing up appropriate policies in Indian context would reduce numerous problems and burden of elderly. Therefore, greater attention needs to be paid by the policy makers to lessen the challenges and problems that are constantly faced by them.

The recent decades shows that there has been good amount of progress carried out in the quality and quantity of the services for the aged in India. But these improvements are good in the urban areas by using advantage of modern advanced technological package and it is just opposite in the rural areas. If there is a support system of encouraging the senior citizens to form their own groups, they themselves can provide good services to their fellow senior citizens. By doing so, 'a sense of age consciousnesses will be created and this will unite them under one umbrella in order to be of support to one another.

It is also need of the hour to introduce the institutional support to attend to the structural problems of ageing by imparting the required training programmes, conducting orientation course, and involving in mass campaign against the attitude towards the ageing. Apart from advocacy work, engaging in series of research work and training the different levels of specialized workers, the need arises to catalyse the community to empower the elderly. Moreover, it is very much essential to involve the voluntary organisations for networking with International agencies to address the needs and enhance the status of elderly populations.

\section{PROVISIONS OF POLICY TO THE ELDERLY IN INDIA}

Welfare of the elderly population is mentioned to some extent in the articles of the constitutions of India. The role of states in providing social security is addressed by article 41 and the primary duties of the states to raise the nutrition 
level, living conditions and public health is spoken by article 47. As a constitutional measure, National Policy on Older Persons (NPOP) in 1999 was evolved by the government of India with a view to realizing inter-sectoral collaboration and cooperation, both within the government as well as between the governmental and non-governmental agencies.

The areas of interventions identified by this policy are the following.

1. To encourage individuals to make provisions for their own, as well their spouse's old age.

2. To encourage families to take care of the older members of their family.

3. To enable and support voluntary and non-governmental organizations to supplement the care provided by the family, with greater emphasis on non-institutional care.

4. To provide care and protection to the elderly, especially widows, the frail, handicapped, abused and destitute elderly.

5. To provide health care facilities especially suited to the elderly.

6. To create awareness regarding elderly persons to develop themselves into fully independent citizens.

Facilitating the implementation of the above policy is rested with the Ministry of Social Justice and Empowerment (MSJE). Also the government constituted National Council for Older Persons with the following objectives

1. To advise the government on policies and programmes for older persons.

2. To provide feedback to the government on the implementation of NPOP as well as on the specific programmes initiatives for older persons.

3. To advocate the best interests of older persons.

4. To provide concessions, rebates and discounts for older persons both with the government as well as with the corporate sector.

5. To suggest steps to make old age productive and interesting

The Government of India has the complete responsibility for implementing the programmes for aged welfare as evolved by it from time to time.

\section{OLD AGE WELFARE PROGRAMMES}

1. The National Social Assistance Programme (NSAP) launched in 1995 for providing monthly financial assistance to the destitute elders. Now, they get Rs.1000/- per month.

2. Non-Governmental organizations are supported through social projects by the central government to provide necessary care and support to elderly people within the community setting.

3. 'Annapurna scheme' was launched by the governed of India on 19th March, 1999, to take care of the elderly destitute. As of now, this scheme helps them to get 35 $\mathrm{kg}$ of ice and $5 \mathrm{~kg}$ of wheat through the Public Distribution System for free of cost. If not, they will be eligible to receive old age pension under National Old Age Pension Scheme.

4. Helpline facilities and care for the elderly are carried out by Age Well Foundation supported by the Ministry of Social Justice and Empowerment.

5. National Programme for Health Care of Elderly (NPHCE) was launched by XI Five Year Plan by the Ministry of Health and Family Welfare (MOHFW) to provide an easy access to preventive, curative and rehabilitative services to the elderly to make the best use of the community based primary health care approach and strengthen capacity of the medical and paramedical professionals; also to provide referral services to the elderly patients through district hospitals, medical colleges, and strengthen health manpower development in the field of geriatric medicine.

\section{A. Inadequacy of Welfare Programmes for the Elderly}

1. The Government of India has been facing numerous pressing problems and therefore, it does not have sufficient sources to allocate decent ad required funds to care the elderly. Not only various individual persons but also the organisations standing for the rights and welfare of the elderly and the needy have been pressing the Government to introduce a National Policy for their welfare.

2. A strong emphasis has been given to voices of older people and the needs of them as perceived by elderly themselves.

\section{CONCLUSION}

Geriatric population is rising at a faster rate due to demographic transition. Like elsewhere in the world, elderly needs to be paid special attention in India due to the problems of economic insecurity, abject poverty, and landlessness, condition of poor health and lack of welfare services. The living conditions of the elderly in India are affected by situations of social exclusion, lack of opportunities to participate in development activities, extremely limited access to health care, and shortage of funds for the provision of monthly pension schemes, poor social service networks and dilapidated condition of their housing. All these factors are responsible for the suffering of the elderly and also failing to meet minimum conditions of dignity to elders. It is need of the hour to increase awareness on aging population and its public health consequences among the policy and decision-makers. They need to devise policies through the results of research in order to improve the quality of life in old age. Though there are many policies and programmes in existence in India for the welfare of elderly, care needs to be taken to improve the socio-economic and living conditions of the poor, destitute and uneducated elderly staying in the rural areas. 


\section{REFERENCES}

[1] Alam, Moneer. (2007, 12-15 April). Ageing, Socio-Economic Disparities and Health Outcomes: Some Evidence from Rural India. Paper presented at the Conference Titled 'Expanding Freedom: towards social and economic transformation in a globalising world. Organized by Institute of Economic Growth, Delhi.

[2] Ansari. (2000). Are the Elderly a Burden? An Examination of Their Conditions in Rural Bihar. Man in India.

[3] Arun P. Bali, Ed. (1999). Understanding Graying People of India, Inter- India Publications, New Delhi.

[4] Bose, A. B. \& K. D. Gangrade, (ed.) (1988). Aging in India: problems and potentialities, Citizenship Development Society, Abhinav Publications, New Delhi.

[5] Somashekharappa, C. A. et al. (2014, July-December). Welfare of the Elderly in India: A Critical Appraisal, Research Process, 2(2), 62-71 (C) Social Research Foundation.

[6] Chaudhury, D. P. (1992). Aging and the Aged, United Nations Population Report, Geneva.

[7] Gorman M. \& Randel, J. et al., eds. (1999). Poverty, Independence and the World's older people in Earthscan Publications Ltd., London. Help Age India (2010). Retrieved from (http: //www.helpageindia. org/images/pdf/annual\%20reports/Annual\%20Report\%202010-11. pdf).
[8] Kahn, M. Z. (1995). Services for the Elderly in India. Research and Development Journal.

[9] Mala Kapur Shankardass. (1995). Towards the Welfare of Elderly in India. Revista Mundial De Sociologia, Special Issue on Sociology of Ageing (1), 95-108.

[10] MOSJE. (1999). National Policy on Older Persons, 1999, Ministry of Social Justice and Empowerment, Government of India, New Delhi. Retrieved from http://socialjustice.nic.in/writereaddata/Upload File/ National\%20Policy\%20for\%20Older\%20Persons\%20Year\%201999. pdf

[11] ORGI. (2011). Census of India, 2011, Office of the Registrar General and the Census Commissioner of India, Ministry of Home Affairs, Government of India, New Delhi. www.censusindia.gov.in.

[12] Irudaya Rajan, S. et al. (1999). India's Elderly: Burden or Challenge? Sage Publication, New Delhi.

[13] Siva Raju (ed.) (2011). Voice of the Elderly in India. B.R. Publications Co. \& All India Senior Citizens' Confederation (AISCCON), New Delhi

[14] Sujaya, C. P. (2000, April). National Policy on Older Persons", Seminar 288, 14-20.

[15] W. Andrew. Achenbaum. (1995). Crossing Frontiers: Gerontology Emerges as a Science, Cambridge University Press, New York.

[16] WHO. (2001). World Health Report Mental Health, New Understanding New Hope, Geneva. 